InVisible Culture • Issue 33: After Douglas Crimp

\title{
After Douglas Crimp \\ Questionnaire Response: \\ Catherine Zuromskis
}

\section{Catherine Zuromskis}

Published on: Jan 05, 2022

DOI: 10.47761/494a02f6.0502f0aa

License: Creative Commons Attribution 4.0 International License (CC-BY 4.0). 


\section{How to do Intimacy}

Douglas was a great teacher. He was my favorite teacher. He was also my mentor, dissertation advisor, role model, dear friend, sometime parent, and generally, among the best people I have ever had the pleasure to know. If he were here now, I would tell him that, though I suspect he already knew. I professed my love to him more than once, and usually in an awkward, flustered, effusive rush. In the almost two decades that I knew him, I never quite got over my crush on Douglas. I was so in awe of him, so honored to be able to work with him, and so eager to impress him that it was often hard for me to keep my cool around him. My first job after grad school was at UC Berkeley, and we invited Douglas to give a talk. I got to introduce him. I remember that the podium was too low and the light was too dim so I had to hold my notes up to read them. I was mortified to discover that my hands were visibly shaking with nerves as I stood before a lecture hall full of people and told Douglas how wonderful he was. He responded, as ever, with grace and tenderness. Maybe he was just used to this kind of devotion from his students, but Douglas was also really great at intimacy.

The InVisible Culture questionnaire asks about leisure and the relationship between academia and personal life. It also asks about the relationship between activism, art, and academia. Douglas cultivated this kind of cross-pollination in his writing and in his life through a serious and dedicated practice of intimacy-cultivating intimacy with the reader and with the text; building his engagement with politics and ideas through personal pleasures, desires and relationships; being open and vulnerable in his public and intellectual life as in his private life. This practice of intimacy is, as Douglas demonstrated, essential to the work of visual studies. It is also not easy. I wrote my dissertation on snapshot photography. Perhaps the trickiest thing about the subject was figuring out how to discuss the complex emotional meanings of personal photographs without being maudlin or nostalgic on the one hand, or overly cool and clinical on the other. A snapshot can be intensely personal, freighted with individual feeling and memories, but those feelings are also a product of cultural conventions, market forces, and ideological biases. Douglas's ability to make the personal political (and vice versa) and to unearth otherwise overlooked cultural complexities through intimacy was critical to my own understanding of how private photographs take on public meanings.

His last book, Before Pictures, is a memoir and probably his most intimate book. It is also a photo album of sorts, a compilation of intimate images in which he offers the 
reader glimpses of his boyfriends, his personal style, his office, and his bedroom. He invites us along with him to the beach, the discotheque, and the ballet. In the context of the book, even more public images are filtered through his personal experience, adding layers of nuance and poignancy. Of a Garry Winogrand photograph taken at a Guggenheim Museum party he attended in 1970, Douglas writes that the reader "will have to take it on faith" that the slender elegant fingers extending in from the left edge of the frame are his. It's a great photograph and distinctively Winogrand's, with its frame slightly off kilter and the odd spontaneous composition of extended limbs zig zagging across the picture plane. But there is also the punctum of Douglas's fingers, almost completely blown out by the flash, and yet immediately recognizable to me. Faith isn't really necessary-they are so uniquely his.

But it is not just Before Pictures; everything he wrote was suffused with a kind of intimacy. His game changing intellectual leaps and activism were often borne of intimate acts and observations. Whether it was a visit with family, browsing the stacks at the library, a one night stand, or his own HIV seroconversion, the intimate and sometimes mundane events of Douglas's life were vital to his (and our) understanding of aesthetics, politics, and indeed intimacy itself. Personal relationships and intimate encounters proliferate throughout his writings. He chronicles instances of sexual intimacy, love, and companionship in ways that helped define postmodernism, visual culture, and his AIDS activism. Douglas drew inspiration from people outside of academia to reach a more complete understanding of art in the world-a male visitor to his bedroom who sees Sherrie Levine's Untitled (After Edward Weston) as a dirty picture, his grandmother who schools him on the difference between eyelet embroidery and lace. These encounters are fiercely personal and distinctly outside the realm of academia and the art world, yet they are never superfluous, incidental, or selfindulgent. Rather, they define his situatedness in relationship to his subject, which, in turn, defines art and culture as fundamentally contingent to lived experience. As fluent as he was with theory and art history, it is this practice of living with his ideas and their implications that gave his writings and his politics such urgency and impact.

This practice of intimacy with his ideas was most evident in Douglas's willingness to revisit his past work to explore it anew. In circling back, having second thoughts, considering his failures, and letting ideas evolve and change, Douglas's work models what is to my mind the ideal approach to writing about contemporary art and culture. His realizations of small shifts and oversights are my favorite moments in his writing, and they are often the most revelatory. Some of the best advice Douglas ever gave me, early on in grad school, was to let my work be messy and to embrace its 
complications. Sometimes, complicating something is the point, he suggested. It is a non-linear approach and, as the questionnaire suggests, a kind of dance, but it is not one I could diagram or choreograph. It is an improvisation born of holding one's ideas close, listening and feeling, not shying away from the moments where you may have stumbled, and building on missteps to construct a masterpiece.

Finally, I recall the small intimacies Douglas shared with me: the first time he signed an email to me "love, Douglas"; the first time he gave me a kiss, after I picked him up at the airport; the time we discovered our shared love of dance and our many discussions about food and cooking. Once, I bumped into him while boarding a Rochester-to-JFK flight and we sat together-he was appalled to discover I had not yet seen any of the films of Rainer Werner Fassbinder. Another time, shortly before he got sick, I was walking through the Mission in San Francisco when I heard my name. It was Douglas, sitting alone in a small Italian restaurant at a table by the window. $\mathrm{He}$ invited me to join him and we had a leisurely lunch together. That evening, he gave a reading from Before Pictures at The Lab and I went. Afterwards, he signed my copy of the book. My hands shaking just a little, I told him once more how wonderful he was.

Catherine Zuromskis is an associate professor in the School of Photography at Rochester Institute of Technology and the author of Snapshot Photography: The Lives of Images (MIT Press, 2013).

$\underline{\text { Click here to return to the other questionnaire responses. }}$ 